Brasileiro. Porto Alegre: Ed. Livraria do Advogado, 1995 .

24 - WENDT, Rudolf. Anmerkungen zu Art. 14 GG. in: M. Sachs (Org), Grundgesetz Kommentar. München: C.H. Beck, 1996.
25 - ZACHER, Hans-Friedrich. Das soziale Staatsziel. in: J. Isensee/P. Kirchhof (Org.), Handbuch des Staatsrechts der Bundesrepublik Deutschland. Vol. I, Heidelberg: C.F. Müller, 1987, pp. 1045 e ss.

\section{Do Positivismo Jurídico à Democracia em Kelsen}

\author{
Losé Levi e Mello do eAmaxal Líniose
}

Professor de Direito Constitucional da PUC/RS

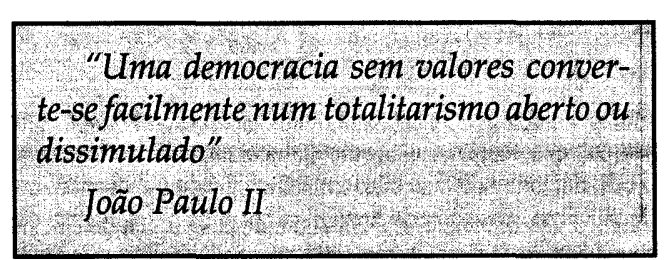

\begin{tabular}{|c|}
\hline SUMÁRIO \\
1. Introdução; \\
2. O conceito de Direito em Kelsen; \\
3. O jogo democrático em Kelsen; \\
4. Cruzando o limiar da democracia \\
kelseniana; \\
5. Referências bibliográficas. \\
\hline
\end{tabular}

\section{Introdução}

ANS KELSEN, provavelmente o maior jurista do Século XX, tem recebido toda sorte de interpretações e críticas. Afinal, sua vasta e singularmente articulada obra é alvo dos mais sérios debates doutrinários das últimas décadas. Analisar o conceito de Direito em KELSEN, bem como seus reflexos na concepção de democracia proposta pelo mesmo autor, é o objeto do presente estudo.

Para isso, iniciaremos enfrentando o conceito de Direito em KELSEN; a seguir estudaremos o modelo democrático por ele defendido; à guisa de conclusão, enfocaremos a forma pela qual a concepção de Direito exposta determina a teoria kelseniana de Estado democrático, a fim de precisar a influência daquele conceito sobre a dinâmica do jogo democrático tal qual proposto pelo jurista austríaco.

\section{0 conceito de Direito em Kelsen}

O dissenso e o embate ideológico marcam, profundamente, a sociedade 
contemporânea. ${ }^{1}$ A conciliação das diferen tes inclinações político-ideológicas da sociedade contemporânea, precisamente, é a tarefa empreendida pelo positivismo jurídi co. $^{2}$

O positivismo jurídico tem sua sistematização clássica na "escola alemã de direito público", de LABAND e GERBER Para seus adeptos, o Direito é um sistema pleno, sem lacunas e autônomo, ${ }^{3}$ dentro do qual não há espaço para juízos de valor morais ou políticos. ${ }^{4}$ Enquanto jusnaturalismo pauta o Direito pela justiça das suas normas, e o realismo define o $\mathrm{Di}$ reito pela eficácia daquelas, o positivismo faz o Direito depender da validade dos seus comandos normativos:" "norma jurídica não é a norma justa ou a norma eficaz, é a norma

válida" ${ }^{6}$ Essa concepção do jurídico teve sua mais elaborada formulação na obra de KELSEN.

Em KELSEN, o Direito apresenta-se como um sistema normativo - formado por normas válidas e coercitivas -, que funciona como um "esquema de interpretação" a conferir sentido jurídico aos atos humanos. ${ }^{7}$ Assim, uma conduta humana é juridicamente relevante se coincide com o conteúdo de uma norma válida. ${ }^{8}$

A pretensão dessa concepção de Direito é descrever o Direito como ele é, não dizer como ele deveria ser. ${ }^{9}$ Para melhor compreender a construção, importa analisar algumas das categorias com que trabalha KELSEN.

1. "Com a Reforma, há uma cisăo na cosmovisão ocidental. No mesmo espaço geográfico, encontram-se agora indivíduos com visões de mundo e valores diversos. Não há mais valores 'objetivos', que recebam a adesăo generalizada. 0 dissenso em relação aos valores fez com que estes fossem relegados à esfera privada, tornando todo juizo avaliativo apenas a expressão de uma preferência subjetiva. A modernidade traz à luz a sociedade pluralista, aquela onde impera, para utilizar a expressão de Weber, 'o politeísmo de valores'. Nesse contexto, 0 apelo à justiça, entendida como qualquer qualidade ético-política que torne uma norma merecedora de obediência, é fator de insegurança na identificação do jurídico, na medida em que os valores, formadores do âmbito moral da vida social, carecem de um conteúdo objetivo" (Barzotto, Luís Fernando. Positivismo jurídico contem-

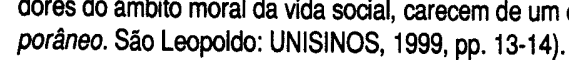

2. A sociedade medieval já era uma sociedade pluralista; ocorre que cada grupo ou estamento dessa sociedade regia-se por um estatuto jurídico próprio. É com a formação do Estado moderno que esses difierentes grupos se submetem a uma mesma ordem juridica, uma ordem jurídica monista, uma vez que emanada de um Estado que monopoliza a produção do Direito (ct. Bobbio, Norberto. O positivismo jurídico: liçöes de filosofia do direito. São Paulo: lcone, 1995, p. 27). "Nesse novo mundo, o direito positivo torna-se o principal meio de integração social e a única garantia do indivíduo contra o poder estatal" (Barzotto, op. cit., p.
138).

3. "....as normas positivas podem ter lacunas, porém o Direito - ou, mais exatamente, o ordenamento jurídico - não" (Araújo, José Estévez. La crisis del estado de derecho liberal — Schimitt en Weimar, Barcelona: Ariel: 1989, p. 74).

4. Cf. Araújo, op. cit., pp. 74-76.

5. Cf. Barzotto, op. cit., pp. 19-20. "Norma válida é aquela que pertence ao sistema por ter sido produzida de acordo com outras normas válidas do sistema" (Barzotto, op. cit., p. 139).

6. Barzotto, op. cit, p. 20.

7. Cf. Kelsen, Hans. Teoria pura do direito. São Paulo: Martins Fontes, 1998, p. 4.

8. Cf. Kelsen, Teoria pura do direito..., p. 5.

9. Cf. Kelsen, Teoria pura do direito..., p. 1. A esse respeito, Dworkin aduz que, em regra, os juristas sabem o que é o Direito, compreendem, com clareza, o que as normas "querem" expressar. No entanto, as controvérsias jurílicas afloram e se acirram na medida em que os intérpretes do Direito tentam fazer valer as suas concepcőes de como deveria sero Direito, năo raro atribuindo interpretaç̧es dissonantes do significado claro e literal da norma (cf. Dworkin, Ronald. O império do Direito. São Paulo: Martins Fontes, 1999, p. 11 e ss).

Revista da Faculdade de Direito da UFRGS, v. 17, 1999
Norma jurídica. A norma jurídica é um dever-ser e o ato humano ao qual ela atribui significado é um $s e .^{10}$ Esse ato será conforme o Direito se coincidir, em seu conteúdo, com o conteúdo da norma. O conteúdo da norma pode ser um comandar, um permitir e um conferir competência. ${ }^{11}$ Eventual divergência entre o ato e o conteúdo da norma implica em uma sanção socialmente organizada. ${ }^{12}$

Validade. Para incidir nos fatos da vida e atribuir-lhes efeitos jurídicos, a norma precisa ser válida. Para KELSEN, a validade é a qualidade da norma que: (1) existe juridicamente, ${ }^{13}$ isto é, (2) pertence a um ordenamento jurídico, ${ }^{14}$ (3) posto que criada segundo o modo prescrito por outra nor- ma do sistema ${ }^{15}$ (4) de forma a obrigar os homens a se comportarem segundo o conteúdo normativo. ${ }^{16}$ Portanto, uma norma existe e obriga na medida em que foi produzida conforme o prescrito em uma norma superior. ${ }^{17}$ Cria-se, assim, uma "cadeia normativa" de normas postas. ${ }^{18}$ Para que esse encadeamento não caia no infinito, KELSEN pressupõe uma norma hipotética que, pretensamente, fecha o sistema: a norma fundamental.

Norma fundamental. Para completar o projeto positivista, KELSEN não pode fechar o seu sistema normativo com um dado fático ou moral. ${ }^{19} \mathrm{O}$ próprio Direito deve fundar o sistema normativo. Chegase, assim, à norma fundamental, uma nor-

10. A distinçăo ser e dever-ser, segundo o próprio Kelsen, "é um dado imediato da nossa consciência", não podendo ser mais aprofundada (ct. Kelsen, Teoria pura do direito..., p. 6).

11. Cf. Kelsen, Teoria pura do direito..., p. 6.

12. Cf. Kelsen, Teoria pura do direito..., p. 71. É esse dado - a presença de um sistema coercitivo socialmente organizado - que, para Kelsen, distingue Direito e Moral (cf. Kelsen, op. cit., p. 71).

13. Cf. Barzotto, op. cit., p. 36.

14. Cf. Barzotto, op. cit., p. 37.

15. Cf. Barzotto, op. cit., p. 37. A conformidade entre a norma inferior criada e a norma superior de criação (regularidade) é verificada por três critérios: (1) observância do procedimento de feitura (processo legislativo); (2) elaboração pela autoridade competente; e (3) compatibilidade entre o conteúdo da norma inferior ao conteúdo da norma superior - cf. Kelsen, Hans. La garanzia

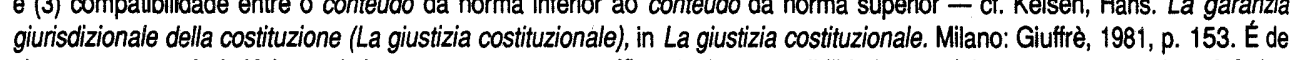
giurisdizionale della costituzione (La giustizia costituzionale), in La giustizia costituzionale. Milano: Giuffrè, 1981, p. 153 . E de "Se o direito positivo conhece uma específica forma constitucional, distinta da forma da lei ordinária, nada se opōe a que essa "Se o direito positivo conhece uma espećfica forma constitucional, distinta da forma da lei ordinária, nada se opõe a que essa

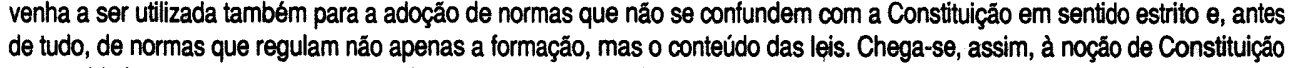
de tudo, de normas que regulam năo apenas a formaçăo, mas o conteúdo das leis. Chega-se, assim, à noçăo de Constituiçắ em sentido lato, que encontramos quando as constituiçőes modernas contêm não apenas regras sobre órgãos e procedimentos legislativos, mas também um elenco de direitos fundamentais dos indivíduos ou liberdades individuais. Desse modo - no
sentido originário senão exclusivo dessa práxis - a Constituição traça princípios, diretivas e limites ao conteúdo das leis futuras" sentido originário senão exclusivo dessa práxis - a Constituição traça principios, diretivas e limites ao conteúdo das leis futuras"
(Kelsen, La garanzia..., p. 153). De qualquer forma, como se verá a seguir, Kelsen não admite questionar o acerto ou o desacerto do conteúdo material das normas; o que importa é que haja compatibilidade entre as normas do sistema.

16. Cf. Barzotto, op. cit., p. 39

17. Cf. Barzotto, op. cit., p. 40

18. Cf. Barzotto, op. cit., p. 40.

19. "Kelsen não pode recorrer a uma instância moral para alcançar uma tundamentaçăo do direito positivo, uma vez que, para ele, recorrer a uma norma moral acarretaria uma 'moralização' do fenómeno jurídico. Ele não pode recorrer também a uma norma fundamental fática, devido à estrita separaçáo que mantém entre as esferas do ser e do dever ser" (Barzotto, op. cit., pp. 40-41). 
ma jurídica hipotética, não posta mas pressuposta, que funciona como fundamento de validade último de todo o sistema normativo kelseniano, ${ }^{20}$ assim podendo ser enunciada: "devemos obedecer às ordens do autor da Constituição", ${ }^{21}$ qualquer que seja o conteúdo desta Constituição. ${ }^{22}$

Em KELSEN, não interessa ao $\mathrm{Di}$ reito se uma norma é verdadeira ou falsa, boa ou má, mas tão-somente se ela é válida ou inválida. ${ }^{23} \mathrm{O}$ único juízo de valor admitido por KELSEN é a compatibilidade das condutas humanas às normas, e destas com as normas superiores. ${ }^{24}$
Essa concepção de Direito é aplicada por KELSEN em sua teoria do Estado. Em verdade, para o jurista austríaco, Estado e Direito se confundem. ${ }^{25}$ Essa construção terá implicações marcantes na concepção kelseniana de democracia - e de Estado democrático -, a qual também restará, pretensamente, esvaziada de juízos axiológicos.

\section{0 jogo democrático em Kelsen}

A democracia concebida por KELSEN funda-se em "dois postulados da
20. Cf. Kelsen, Teoria pura do direito..., p. 224 e ss. Essa pretensão de Kelsen - fundar o Direito no próprio Direito - é o que Luís Fernando Barzotto chamou, em sua tese de doutorado, "projeto positivista" (c. Barzotto op. cit., p. 31). Ocorre que o proppro Kelsen acaba abrindo uma "tratura sistemática" (cf. Barzotto, op. cit., p. 62) em sua teoria: "Uma norma jurídica é considerad como objetivamente válida apenas quando a conduta humana que ela regula the corresponde efetivamente, pelo menos numa certa medida. Uma norma que nunca e em parte alguma é aplicada e respeitada, isto é, uma norma que - como costuma dizerse - năo é eficaz em uma certa medida, não será considerada como norma válida (vigente). Um mínimo de efićácia (como dizer-se) é a condição de sua vigência" (Kelsen, Teoria pura do direito plano fático é incoerente. Com efeito, a norma fundamental, ao instituir a eficácia , a relação da norma fundamental com o normas singulares, leva ao paradoxo da porma fundamental, ao instituir a eficácia como condiçăa suficiente da validade das de fato: ela afirma a validade de normas que já são obedecidas e retira a valida vez que ela se limita a reproduzir a realidade Assim, a formulação clássica, 'devemos obedecer às normas emanadas do primeiro normas que náo sáo mais obedecidas. rezasse: 'devemos obedecer às normas eficazes emanadas do constituinte' acima: por que há necessidade de uma norma que manda olas do consiluihte. Mas assim, ela se torna supérflua, como visto fundamental $e$, deste modo, uma soluçăo insatistatória para as relaçoses entre enalida obedecico? A inclusáo da eficácia na norma salvar a corência do sistoma pois um intruso (0 a salvar a coerência do sistema, pois um intruso (o fato) é sempre um intruso, ainda que ocupe o lugar de honra no sistema (a norma fundamental)" (Barzotto, op. cit., p. 66). 21. Kelsen, Teoria pura do direito..., p. 227. Vale dizer, as ordens do constituinte autor da primeira Constituiçåo histórica (cf. Kelsen,
Teoria pura do direito..., p. 227).

22. "Aqui permanece fora de questão qual seja o conteúdo que tem esta Constituçăão e a ordem jurídica estadual erigida com base nela, se esta ordem é justa ou injusta; e também năo importa a questăo de saber se esta ordem jurídica efetivamente garante uma relativa situação de paz dentro da comunidade por ela constituída. Na pressuposiçắo da norma fundamental não é afirmado qualquer valor transcendente ao Direito positivo" (Kelsen, Teoria pura do direito.... p. 227).

23. Cf. Kelsen, Teoria pura do direito..., p. 21.

24. Cf. Kelsen, Teoria pura do direito..., p. 19. "A resposta à questão de saber se, de acordo com o Direito vigente, um assassino deve ser punido com a pena capital, $e$, assim, se a pena de morte para o homicida é valiosa com esse Direito, pode e deve verificar-se sem ter em conta se aquele que deve dar a resposta aprova ou desaprova a pena de morte. Então, e somente então, é objetivo esse juizo de valor" (Kelsen, Teoria pura do direito..., p. 23).

25. "Do ponto de vista de um positivismo jurídico coerente, o Direito, precisamente como o Estado, não pode ser concebido senão como uma ordem coerciva de conduta humana - com o que nada se afirma sobre o seu valor moral ou de Justiça. $E$, então, 0 Estado pode ser juridicamente apreendido como sendo o próprio Direito - nada mais, nada menos" (Kelsen, Teoria pura do direito..., p. 353). "O Estado não é pois, nem pessoa distinta do Direito, nem poder que está atrás do Direito garantindo-0, mas sim o Estado é o próprio Direiton" (Araújo, op. cit., p. 100). nossa razão prática": ${ }^{26}$ liberdade e igualdade. $^{27}$

No momento em que o homem se organiza em sociedade, paulatinamente configura-se um aparato estatal que disciplinará as relações dos homens entre si e destes com o Estado. Surge, então, um podade. Ora, sendo a liberdade ínsita a cada ser humano, devemos ser comandados por nós mesmos. ${ }^{28}$ Portanto, para KELSEN, o homem é livre na medida em que participa da formação da vontade do Estado. ${ }^{29} \mathrm{De}$ qualquer forma, "...mesmo que a vontade geral seja realizada diretamente pelo povo, der que comandará o indivíduo e a socie- o indivíduo é livre só por um momento, isto é, durante a votação, mas apenas se votou com a maioria e não com a minoria vencida". ${ }^{30}$

Assim, KELSEN afirma que "o cidadão só é livre através da vontade geral e de que, por conseguinte, ao ser obrigado a obedecer ele está sendo obrigado a ser livre". ${ }^{31}$ Surge, aqui, um dos dramas do modelo: a vontade geral vale objetivamente, isto é, independe da vontade daqueles que se the submetem..$^{32}$ Esta realidade fica ainda mais evidente quando o votante muda de opinião, uma vez que tal câmbio não traz qualquer conseqüência jurídica. ${ }^{33}$ Ademais, deve-se lembrar que a maioria das pessoas
26. Cf. Kelsen, Hans. A essência e o valor da democracia, in $A$ democracia. São Paulo: Martins Fontes, 1993, p. 27.

27. "É a própria natureza que, exigindo liberdade, se rebela contra a sociedade. $O$ peso da vontade alheia, imposto pela vida em sociedade, parece tanto mais opressivo quanto mais diretamente se exprime no homem o sentimento primitivo do próprio valor. ensina que, se quisermos ser realmente todos iguais, deveremos deixar-nos comandar. Por isso a ideologia política năo renuncia a unir liberdade com igualdade. A síntese desses dois princípios é justamente a característica da democracian (Kelsen, op. cit., p. 27). "Sem a fé das massas no poder e na missãos divina do ditador, nenhuma ditadura pode resistir por muito tempo ao indestrutivel anseio de liberdade, e esta terminará sempre por levar a melhor sobre aquela" (Kelsen, Hans. O problema do parlamentarismo, in $A$ democracia. Săo Paulo: Martins Fontes, 1993, p. 134).

28. Cf. Kelsen. A esséncia..., p. 28. "A liberdade natural transforma-se em liberdade social ou politica. É politicamente livre aquele que está submetido, sim, mas à vontade própria e não alheia" (Kelsen. A essência..., p. 28). Para Kelsen, "a democracia contentase com uma simples aproximação do conceito originário de liberdade" (Kelsen. O problema..., p. 127). "A democracia, no plano da idéia, é uma forma de Estado e de sociedade em que a vontade geral, ou, sem tantas metáforas, a ordem social, é realizada por quem está submetido a essa ordem, isto é, pelo povo" (Kelsen. A essência..., p. 35).

29. É de notar que Kelsen iguala um típico direito fundamental - a liberdade - com o direito político de votar. O próprio Kelsen 0 reconhece: "os direitos polliticos - isto é, a liberdade - reduzem-se a um simples direito de voto" (Kelsen. A essência..., p. 43). Merece crítica tal entendimento. Os direitos fundamentais, ou liberdades públicas (poderes de agir perante o Estado e a sociedade) decorrem da dignidade da pessoa humana, independentemente de qualquer intermediação, seja do Estado, seja da sociedade; por sua vez, os direitos políticos (participação na formaçăo da vontade geral - cf. Kelsen, $A$ essência.... p. 37), dependem da de; por sua vez, os direitos politicos (participaçáa na formaçáa da vontade geral - ct. Kelsen, $A$ essencia..., $p .37$, dependem da
inserçăo da pessoa humana em um Estado que a reconheça como seu nacional, isto 6 , os direitos políticos decorrem da nacioinserçáo da pessoa humana em um Estado que a reconheça como seu nacional, isto é, os direitos políticos decorrem da nacionalidade. É de destacar que Kelsen já defendia a desvinculação entre direitos politicos e nacionalidade

30. Kelsen, $A$ essência..., p. 29. Vale lembrar o que é a vontade geral: "...é a razão, a voz da razão que os homens ouvem sobre 0 interesse geral, quando se despem do interesse privado e não estão sob a influência de associaçóes particulares [livres, portanto, das pressóes de partidos políticos e lobbies - nota nossal" (Ferreira Filho, Manoel Goncalves. Do processo legislativo, $3^{\mathrm{a}}$ edição, São Paulo: Saraiva, 1995, p. 47). De qualquer forma, se em Rosseau, defensor ferrenho da democracia direta, os partidos políticos são condenados, em Kelsen como se veŕa a seguir, eles passam a ser aclamados como os principais atores do jogo pollitico (Kelsen, $A$ essência...., p. 39).

31. Cf. Kelsen, $A$ essência..., p. 34

32. Cf. Kelsen, $A$ essência..., p. 30

33. Cf. Kelsen, A essência..., pp. 30-31.

Revista da Faculdade de Direito da UFRGS, v. 17, 1999 
já nasce numa ordem estatal preexistente, isto é, para cuja criação e configuração não concorreu. ${ }^{34}$ Por tudo isso, a exigência de uma maioria absoluta para tomada de decisão representa uma aproximação maior com a idéia de liberdade. ${ }^{35}$

A pretensão do sistema é que a maioria represente também a minoria, isto é, a vontade da maioria seria expressão da vontade geral. Mas isso é mera ficção. ${ }^{36} \mathrm{~A}$ minoria conserva seus ideais, devendo ter à sua disposição meios de influir na vontade da maioria. Caso contrário, cedo ou tarde renunciará à participação meramente formal; em isso acontecendo, a maioria desnatura-se, uma vez que só há maioria se houver uma minoria.... ${ }^{37} \mathrm{E}$, não havendo contraposição entre maioria e minoria, não há democracia!

Ganha relevo, então, a questão da proteção da minoria. "Esta proteção da minoria é a função essencial dos chamados direitos fundamentais e liberdades fundamentais, ou direitos do homem e do cidadão, garantidos por todas as modermas constituições das democracias parlamentares". ${ }^{38}$ Em KELSEN, a proteção da minoria através da garantia das liberdades públicas, será desempenhada por uma jurisdição constitucional. ${ }^{39}$

Os conflitos sociais, intensos no ocaso do Século XIX, foram conduzidos para dentro do parlamento. Supera-se a democracia liberal, onde não havia partidos políticos e o consensus em torno da ordem liberal vigente era mantido pelo voto censitário. 40 Até então, por força das instituições liberais, as demandas populares eram mantidas distantes do Parlamento, uma vez que esse

34. Cf. Kelsen, $A$ essência..., p. 31 .

35. Cf. Kelsen, A esséncia..., p. 31. "...se nem todos os individuos são livres, pelo menos o seu maior número o é" (Kelsen, $A$ essência..., p. 32).

36. C. Kelsen, A essência..., p. 69.

37. Cf. Kelsen, A essência..., p. 70. "Portanto, seria melhor dar a tal princípio [princípio majoritário - nota nossa] o nome de princípio majoritário-minoritário, uma vez que ele organiza o conjunto dos indivíduos em apenas dois grupos essenciais, maioria e minoria oferecendo a possibilidade de um compromisso na formaçáo da vontade geral, depois de ter preparado esta útima integraçăa obrigando ao compromisso acima mencionado, que é a única coisa que pode permitir a formação tanto do grupo da maioria quanto do grupo da minoria: relegar a segundo plano o que separa os elementos a serem unidos, em fovor daquilo que unia quanto do grupo da minoria: relegar a segundo plano o que separa os elementos a serem unidos, em favor daquilo que un

38. Kelsen, $A$ essência..., p. 67.

39. Kelsen. La garanzia..., p. 202. "Enquanto assegura a formaçáo constitucional das leis e em particular a constitucionalidade material das mesmas, esta [a jurisdição constitucional - nota nossa] é um meio de proteção eficaz da minoria contra os abusos da maioria. Odomínio desta última é suportível apenas se exercido de modo ro na onipotência da maioria mas no onntanto mpromisso entra e, portanto na paz social a justica constitucion surgo

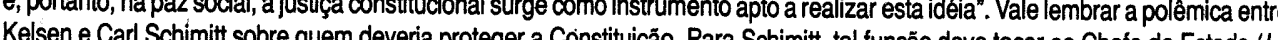
defen estado (La defensa de la Constiución. Barcelona: Editorial Labor, 1931); para Kelsen, como visto, a proteçäo da Constituiçáo deve caber a uma jurisdiçáo constitucional (vide, em especial, o trabalho Chi dev'essere il custode della Costituzione?in La giustizia costituzionale. Milano: Giuffrè, 1981, p. 229 e ss., elaborado em reposta à crítica de Carl Schimitt).

40. Voto censitário "é a restriçăo do direito de voto àquelas pessoas que pudessem comprovar determinadas exigências indicativas de situação de independência económica (ou propriedade de imóveis, ou determinada renda anual, ou recolhimento de impostos, etc...)" (Souza Jr., Cezar Saldanha. O consensus no estado democrático ocidental, tese de doutorado. São Paulo: USP, 1984, p.
161).

Revista da Faculdade de Direito da UFRGS, v. 17, 1999 era composto exclusivamente por políticos

Fazendo forte crítica ao marxismo que, em última análise, propugnava pela KELSEN defenderá uma democracia com sufrágio universal ${ }^{42}$ e realizada por meio dos partidos políticos. Esses são aclamados como "um dos elementos mais importantes da democracia real". ${ }^{43}$ É por meio deles que os homens de mesma opinião se agrupam para influir sobre a gestão dos negócios públi$\cos { }^{44}$ é através deles que os conflitos sociais harmonizam-se no embate pacífico do jogo político-partidário típico dos parlamentos modernos. ${ }^{45}$ fechados com a ordem liberal vigente. ${ }^{41}$ revolução social por meio da força -,

Ainda assim a democracia é sujeita a equívocos. Em alguns dos seus trabalhos, ${ }^{46}$ KELSEN adverte sobre a possibilidade de equívocos ratificados pelo regime democrático; exemplifica referindo a passagem evangélica de "Cristo-Rei" (Jo. 18, 28-40):

"O capítulo XVIII do Evangelho de São João descreve o julgamento de Jesus. Esta história simples, com suas palauras singelas, é uma das composições mais sublimes da literatura mundial, e, sem pretendê-lo, transforma-se num trágico símbolo do antagonismo entre absolutismo e relativismo [segundo o próprio KELSEN, símbolo trágico, também, da democracia - nota nossa - cf. KELSEN, A Essência..., pág. 107].

1. O intuito do voto censitário era "afastar do sufrágio aquelas camadas sociais que não tendo nada a perder, pudessem, de um modo ou de outro, desviar o comportamento do Estado dos rígidos padröes do figurino liberal" (Souza Jr., op. cit., p. 161).

42. Em verdade, os politicos socialistas não queriam o sufrágio universal: queriam fazer valer sua ideologia política pela revolução (ct. Ferreira Filho, op. cit., p. 83). 0 Estado Social Contemporâneo e o voto universal (mecanismo esse que acabou de vez com o Estado Liberal - cf. Ferreira Filho, op. cit., p. 84) não foram talhados por políticos socialistas, mas por politicos conservadores pragmáticos, cientes de que se não fizessem concessōes seriam alijados do poder (cf. Souza Jr., op. cit., p. 208 e ss.).

43. Kelsen, $A$ essência..., pp. 38-39.

44. Ct. Kelsen, $A$ essência..., p. 39. "Os impulsos provenientes dos partidos políticos são como numerosas fontes subterrâneas que alimentam um rio que só sai à superficie na assembléia popular ou no parlamento, para depois correr em leito único do lado de alimentam um rio que só sai à supe (Kelsen, $A$ essência..., p. 39).

45. "...a democracia é o ponto de equilibrio para o qual sempre deverá voltar o pêndulo político, que oscila para a direita e para a esquerda. E se, como sustenta a crítica feroz que o marxismo faz à democracia burguesa, o elemento decisivo é representado pelas relaçoes reais das forças sociais, entáo a forma democrática parlamentar, com seu princípio majoritário-minoritário que constitui uma divisăo essencial em dois campos, será expressão 'verdadeira' da sociedade hoje dividida em duas classes essenciais. E, se há uma forma política que ofereça a possibilidade de resolver pacificamente esse conflito de classes, deplorável mas inegável, sem levá-lo a uma catástrớe pela via cruenta da revolução, essa forma só pode ser a da democracia parlamentar, cuja ideologia é, sim, a liberdade, não alcançável na realidade social, mas cuja realidade é a paz" (Kelsen, $A$ esséncia..., p. 78). É de destacar, ainda a clareza com que Kelsen percebeu um dos maiores equivocos do marxismo: a exclusão de toda e qualquer classe social que náo seia a dos proletários: 0 exclusionismo maxista também foi enfrentado pela Doutrina Socia da lquia: "Enquanto o maxismo defendi prosto some

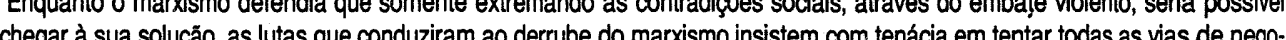
chegar à sua soluça, as lutas que conduziram ao derrube do marxismo insistem com tenácia em tentar todas as vias de negociaça, do dichos do da dignidade humana comum" (Joâo Paulo ll, Papa. Centesimus annus, Så Paulo. Ediçoes Paulinas, 1991, p. 45); "A lgreja está consciente hoje mais do que nunca de que a sua mensagem social encontrara credibilicade primeiro no testemunho das obras e so depols será exclusiva nem discriminatoria relativamente aos outros grupos" (Joäo Paulo ll, op. cit., p. 104). E dentro do parlamento que, permanenturive to, Konrad Hesse, Elementos de direito constitucional alemão, tradução de Luís Afonso Heck, Porto Alegre: Fabris, 1998, p. 29).

46. Kelsen trata do tema em, pelo menos, três trabalhos: $A$ essência e o valor da democracia (in $A$ democracia..., p. 107), Fundamentos da democracia (in $A$ democracia..., pp. 203-204) e Absolutismo e relativismo na filosofia e na politica (in $A$ democracia.... Pp. 356-357) 
"Foi na época da Páscoa que Jesus, acusado de pretender-se Filho de Deus e Rei dos Judeus, foi levado a Pilatos, o delegado romano. E Pilatos, não vendo nele mais que um pobre diabo, perguntou ironicamente: 'Então és tu o rei dos judeus'? Mas Jesus tomou a questão com muita seriedade e, no ardor de sua missão divina, respondeu: 'Tu o dizes. Sou rei. Nasci e vim ao mundo para dar testemunho da verdade. Todo o que está do lado da verdade ouve a minha voz'. Pilatos perguntou então: 'O que é a verdade'? E porque ele, o cético relativista, não sabia o que era a verdade, a verdade absoluta na qual este homem acreditava, procedeu - com muita coerência - de forma democrática, delegando a decisão ao voto popular. Segundo o Evangelho, foi ter novamente com os judeus e disse-lhes: 'Não encontro nele crime algum. Mas é costume que eu, pela Páscoa, vos solte um prisionei ro. Quereis, pois, que eu vos solte o rei dos judeus'? Então gritaram todos novamente, dizendo-lhe: 'Não este, mas Barrabás'. Acrescenta o evangelho: 'Ora, Barrabás era um ladrão'.

"Para os que crêem que o filho de Deus e Rei dos judeus seja testemunha da verdade absoluta, este plebiscito é sem dú vida um forte argumento contra a democracia. E nós, cientistas políticos, temos de aceitar este argumento. Mas com uma con dição apenas: que nós tenhamos tanta certeza de nossa verdade política, a ponto de defendê-la, se necessário, com sangue e lágrimas - que nós tenhamos tanta certeza de nossa verdade quanto tinha, de sua verdade, o filho de Deus." 47

47. Kelsen, Absolutismo..., pp. 356-357.

48. Cf. Kelsen, Absolutismo..., p. 356.

49. Cf. Zagrebelsky, Gustavo. La Crucifixión e la democracia. Barcelona: Ariel, pp. 8-9.

50. Cf. Zagrebelsky, op. cit., p. 9.

51. Cf. Zagrebelsky, op. cit., p. 120.
KELSEN, um relativista declarado, não vê com bons olhos a verdade absoluta anunciada por Jesus Cristo ("Eu sou o $\mathrm{Ca}$ minho, a Verdade e a Vida" - Jo. 14, 6). Não obstante, o próprio KELSEN defende a sua verdade como absoluta: o relativismo ("...que nós tenhamos tanta certeza de nossa verdade política a ponto de defendê-la, se necessário, com sangue e lágrimas - que nós tenhamos tanta certeza de nossa verdade quanto tinha, de sua verdade, o filho de Deus" - texto supra).

Vale mencionar o contraponto desenvolvido por GUSTAVO ZAGREBELSKY. KELSEN apresenta PILATOS como paradigma de democrata: o cético relativista que vai buscar a verdade na maioria popular. ${ }^{48}$ ZAGREBELSKY busca demonstrar que, em verdade, o democrata é Jesus. Para isso, propõe três concepções de democracia: a dogmática, a cética e a crítica. ${ }^{49} \mathrm{~A}$ primeira remete ao absolutismo filosófico e a segunda ao relativismo. A terceira - que o jurista italiano defende - visa uma busca orientada para o melhor, numa criteriosa reflexão acerca das diversas possibilidades políticas. $^{50}$

A multidão enfurecida, bradando "Crucifica-o!", é, justamente, o contrário do que pressupõe a democracia crítica - sem instituições ou procedimentos, totalitária, instável, emotiva, extremista e manipulável. ${ }^{51}$ Para ZAGREBELSKY, Jesus
Cristo é o verdadeiro amigo da democracia - da democracia crítica -, uma vez que, se anuncia uma verdade eterna e universal, não a impõe mas deseja que os homens, no uso livre da sua razão, a alcancem pelo diálogo, pela tolerância e pela reflexão constantes. ${ }^{52}$ Diga-se mais: o uso pleno e criterioso da razão humana, invariavelmente, aponta para essa "Verdade". ${ }^{53}$

\section{Cruzando o limiar da democracia kelseniana}

Apesar da própria advertência, KELSEN mantém seu modelo democrático fundado tão-somente na liberdade e na igualdade. Segue fiel ao seu relativismo filosófico, manifestado em sua concepção de Direito - e, como visto, de Estado -, o qual é, coerentemente, mantido em sua teoria acerca da democracia. Afinal, para KELSEN, a adoção de qualquer verdade axiológica seria uma atitude autocrática. ${ }^{54}$
É este relativismo kelseniano que não poucos criticam..$^{55}$ No entanto, ao contrário do que muitos afirmam apressadamente, este relativismo não foi o único responsável pela bancarrota do modelo democrático alemão pós-1919. O Partido Nazista possuía garantias institucionais para participar do jogo político; afinal, não existiam valores pautando a disputa eleitoral, a não ser a liberdade. De toda sorte, uma vez no poder, o nacional-socialismo poderia ter tido escrutinada sua constitucionalidade à luz da doutrina kelseniana, uma vez que eliminou a liberdade. E não se trata, aqui, de aferir a inconstitucionalidade recorrendo a parâmetros suprapositivos. A liberdade era, sim, valor inerente ao modelo democrático então imperante. ${ }^{56}$

Não obstante, a História nos mostra que o Judiciário alemão acabou por referendar o totalitarismo de Hitler, não porque o modelo de Direito e de democracia

52. Cf. Zagrebelsky, op. cit., p. 121. Importante registrar as palavras finais de Zagrebelsky: "Aestas alturas, próximo do final, devemos restabelecer a justiça a respeito de Hans Kelsen. Sua reflexão sobre o processo de Jesus, como 'caso' da democracia e a

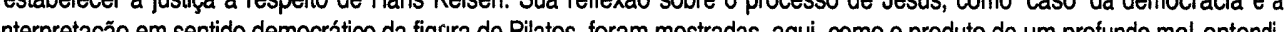
to. 0 co . ens relete perellame iram a validade de um pensamento que constitui uma referência da teoria contemporânea da democracia" (Zagrebelsky, op. cit., p. 120).

53. Cf. João Paulo II, Papa. Fides et ratio. Porto Alegre: EDIPUCRS, 1999, p. 28 e ss:

54. "A tolerância, os direitos das minorias, a liberdade de expressão e a liberdade de pensamento, tão característicos da democracia não têm lugar num sistema político baseado na crença em valores absolutos" (Kelsen, Absolutismo..., p. 355).

55. "... liberalismo almejava um conceito autônomo de direito precisamente para subtrair o direito do arbítrio estatal. $O$ direito é um instrumento de garantia do cidadão contra o poder. 0 conceito de validade garante que somente obedecendo ao direito o poder é capaz de criar direito. Mas, instado pelos fatos a tratar do conceito de eficácia, o positivismo termina por introduzir um critério de juridicidade altamente instável: toda norma eficaz é uma norma jurídica. $O$ direito fica, assim, submetido às vicissitudes do poder. Mas se toda normatividade que se impóe for considerada jurídica, o positivismo termina por trair a missáo que o liberalismo the confiou, de libertar o direito do domínio da força" (Barzotto, op. cit., p. 143). Foi precisamente por esta falha no sistema que o nacional-socialismo penetrou e subverteu as instituiçōes alemãs de Weimar.

56. Se era valor positivo, a liberdade poderia servir como parâmetro apto a ensejar declaraçăo de inconstitucionalidade material (a proposito, o próprio Kelsen: La garanzia..., p. 188 e ss.). 
de KELSEN aclamava o Nazismo ${ }^{57}$ - muito pelo contrário -, mas porque passava à margem do valor maior que rege as relações humanas, isto é, a dignidade da pessoa humana.

É dessa dignidade, ínsita a todo ser humano, que derivam os direitos fundamentais, ${ }^{58}$ aí incluída a liberdade. Mas, se a liberdade ignora sua real origem - a dignidade da pessoa humana -, pode degenerarse em uma liberdade egoísta, ${ }^{59}$ apta a corromper o mais elaborado modelo democrático. ${ }^{60}$ Apenas a liberdade que respeita os demais direitos fundamentais é capaz de realizar, em todo seu esplendor, o ser humano e permitir o convívio social harmônico.

\section{Referências Bibliográficas}

ARAÚJO, José Estévez. La crisis del estado de derecho liberal - Schimitt en Weimar. Barcelona: Ariel, 1989.

BARZOTTO, Luís Fernando. Positivismo jurídico contemporâneo. São Leopoldo: UNISINOS, 1999.

BOBBIO, Norberto. O positivismo jurídico: lições de filosofia do direito. São Paulo: Ícone, 1995.

DALPÉRÉE, Francis. O direito à dignidade humana in Direito constitucional: estudos em homenagem a Manoel Gonçalves Ferreira Filho. São Paulo: Dialética, 1999.

DWORKIN, Ronald. O império do direito. São Paulo: Martins Fontes, 1999.

FERREIRA FILHO, Manoel Gonçalves. Do processo legislativo. 3. ed., São Paulo: Saraiva, 1995.

HESSE, Konrad. Elementos de direito constitucio nal alemão [tradução de Luís Afonso Heck]. Porto Alegre: Fabris, 1998.

JOÃO PAULO II, Papa. Centesimus annus. São Paulo: Edições Paulinas, 1991.

JOÃO PAULO II, Papa. Fides et ratio. Porto Alegre: EDIPUCRS, 1999.

JOÃO PAULO II, Papa. Cruzando o limiar da esperança, 2. ed., Rio de Janeiro: Francisco Alves, 1994.

KELSEN, Hans. A essência e o valor da democracia, in A democracia. São Paulo: Martins Fontes, 1993.

KELSEN, Hans. Absolutismo e relativismo na filosofia e na política, in A democracia. São Paulo: Martins Fontes, 1993.

KELSEN, Hans. Chi dev'essere il custode della costituzione? in La giustizia costituzionale. Milano: Giuffrè, 1981

KELSEN, Hans. La garanzia giurisdizionale della costituzione (La giustizia costituzionale) in La giustizia costituzionale. Milano: Giuffrè, 1981.

57. De qualquer forma, Kelsen não nega caráter jurídico aos Estados totalitários: "Segundo o Direito dos Estados totalitários, o governo tem poder para encerrar em campos de concentração, forçar a quaisquer trabalhos e até matar os indivíduos de opinião, religião ou raça indesejável. Podemos condenar com a maior veemência tais medidas, mas o que não podemos é considerá-las como fora da ordem juríica desses Estados" (Kelsen, Teoria pura do direito..., p. 44).

58. A propósito, Francis Delpérée. O direito à dignidade humana in Direito constitucional: estudos em homenagem a Manoel Gonçalves Ferreira Filho. São Paulo: Dialética, 1999, p. 155 e ss.

59. "Se não se aceita a perspectiva do dom de si mesmo, poderá subsistir sempre o perigo de uma liberdade egoísta. Perigo contra o qual Kant lutou; e, nessa linha, alinharam-se Max Scheler e todos aqueles que, depois dele, compartilharam a sua ética dos valores" (João Paulo ll, Papa. Cruzando o limiar da esperança, $2^{\mathrm{a}}$ ediçăo, Rio de Janeiro: Francisco Alves, 1994, p. 188).

60. "Em nome do princípio democrático não se pode questionar a dignidade inalienável de todo ser humano" (Joăo Paulo ll, Papa. Mensagem dirigida a parlamentares brasileiros em visita à Santa Sé em 1997). "Uma democracia sem valores converte-se facilmente num totalitarismo aberto ou dissimulado, como a história demonstra" (João Paulo II, Papa. Centesimus..., p. 85).

KELSEN, Hans. O problema do parlamentarismo, in A democracia. São Paulo: Martins Fontes, 1993.

KELSEN, Hans. Teoria pura do direito. São Paulo: Martins Fontes, 1998

SCHIMITT, Carl. La defensa de la Constitución. Barcelona: Editorial Labor, 1931.
SOUZA JR., Cezar Saldanha. O consensus no estado democrático ocidental, tese de doutorado. São Paulo: USP, 1984.

ZAGREBELSKY, Gustavo. La crucifixión y la democracia. Barcelona: Ariel, 1996. 